\title{
Production and quality of mini watermelon cv. Smile irrigated with saline water
}

\author{
Alan B. O. de Sousa ${ }^{1}$, Sérgio N. Duarte ${ }^{1}$, Osvaldo N. de Sousa Neto ${ }^{1}$, \\ Ana C. M. Souza ${ }^{2}$, Pedro R. F. Sampaio ${ }^{1} \&$ Carlos T. dos S. Dias ${ }^{3}$ \\ ${ }^{1}$ Universidade de São Paulo/Escola Superior de Agricultura “Luiz de Queiroz"/Departamento de Engenharia de Biossistemas. Piracicaba, SP. E-mail: \\ alan2b@gmail.com (Corresponding author); snduarte@usp.br; sousaneto@usp.br; ramualyson@hotmail.com \\ ${ }^{2}$ Universidade Federal Rural do Semi-Árido/Departamento de Ciências Ambientais e Tecnológicas. Mossoró, RN. E-mail: anaclaudia.gambiental@hotmail.com \\ ${ }^{3}$ Universidade de São Paulo/Escola Superior de Agricultura “Luiz de Queiroz"/Departamento de Ciências Exatas. Piracicaba, SP. E-mail: ctsdias@usp.br
}

\section{Key words:}

salt stress electrical conductivity cucurbitaceae

\begin{abstract}
A B S T R A C T
The purpose of this study was to evaluate the salt tolerance of mini watermelon (cv. Smile). The experiment was carried out in the greenhouse of the Department of Biosystems Engineering of ESALQ/USP. The experimental design was randomized blocks. The plants were irrigated with five levels of salinity $\left(S_{1}=1.0 ; S_{2}=2.0 ; S_{3}=3.0 ; S_{4}=4.0\right.$ and $S_{5}=5.0$ $\mathrm{dS} \mathrm{m} \mathrm{m}^{-1}$ ). At 85 days after the beginning of the experiment, the plants and the physical and chemical variables of the fruit were evaluated. Salinity negatively affected the variables: length of the main stem, stem diameter, number of leaves, number of branches, leaf area, fresh and dry matter. Regarding the physical and chemical characteristics of fruits, salinity reduced the mass, diameter and the $\mathrm{pH}$ of the fruit, but increased its vitamin $\mathrm{C}$ content. In general, the results suggest that the mini watermelon (cv. Smile) is moderately sensitive to salinity.
\end{abstract}

\section{Palavras-chave:}

estresse salino condutividade elétrica cucurbitaceae

\section{Produção e qualidade da minimelancia cv. Smile irrigada com água salina}

\begin{abstract}
R E S U M O
Com o objetivo de estudar a tolerância à salinidade da água de irrigação na minimelancia cv. Smile, um experimento foi conduzido em casa de vegetação do Departamento de Engenharia de Biossistemas da ESALQ/USP. O delineamento experimental adotado foi em blocos casualizados. As plantas foram irrigadas com cinco níveis de salinidade $\left(\mathrm{S}_{1}=1,0 ; \mathrm{S}_{2}=2,0\right.$; $\mathrm{S}_{3}=3,0 ; \mathrm{S}_{4}=4,0$ e $\mathrm{S}_{5}=5,0 \mathrm{dS} \mathrm{\textrm {m } ^ { - 1 }}$ ). Aos 85 dias após o início do experimento avaliaram-se as plantas e as variáveis físico-químicas dos frutos. A salinidade afetou negativamente as variáveis comprimento do ramo principal, diâmetro do caule, número de folhas, número de ramos secundários, área foliar, massa fresca e massa seca. Para as variáveis físico-químicas dos frutos a salinidade reduziu a massa fresca, o diâmetro e o $\mathrm{pH}$ do fruto e elevou o teor de vitamina C. Com os resultados obtidos infere-se que a minimelancia cv. Smile é moderadamente sensível à salinidade.
\end{abstract}




\section{INTRODUCTION}

Watermelon is a typically tropical fruit species with production mainly of large fruits with weight varying from 6 to $25 \mathrm{~kg}$ (Campagnol, 2009). However, there have been changes in the population patterns that led to increasingly smaller families and, as a consequence, a preference for smaller fruits, such as the mini watermelon. Besides size, the color and the absence of seeds in some cultivars increase the added value, constituting a good financial return to the producer.

It is estimated that, out of the $90 \%$ of freshwater available for human consumption, $70 \%$ are destined to agriculture and $22 \%$ to the industry (John \& Marcondes, 2010). Thus, the use of wastewater or low-quality water in agriculture would be a good option, especially in periods of water scarcity, such as in regions with low availability of this natural resource. However, high concentrations of salt in the water and in the soil can affect plant growth, since it can be inhibited by salinity due to the osmotic and ionic effects. The physiological and biochemical functions can be influenced by the excess of salts, resulting in a disorder of water relationships and alterations in absorption and utilization of nutrients (Munns \& Tester, 2008). These responses of the plant to salt stress are related to the sensitivity and/or tolerance of each crop to salinity.

The investigation of crop tolerance to salt stress allows to find out whether the plant can be produced with low-quality water, without reduction in its production; thus, this study aimed to evaluate the tolerance to irrigation water salinity of the mini watermelon, cv. Smile.

\section{Material ANd Methods}

The experiment was carried out in an experimental area of the Department of Biosystems Engineering of the "Luiz de Queiroz" College of Agriculture, of the University of São Paulo (ESALQ/ USP) Piracicaba, SP, Brazil. According to Sentelhas (1998), the climate of the region, based on Köppen's classification, is Cwa, humid tropical with temperatures of the hottest month higher than $22^{\circ} \mathrm{C}$ and coldest month lower than $18^{\circ} \mathrm{C}$.

The seeds of mini watermelon cv. Smile were sown on plastic trays with substrate of coconut fiber, covered with vermiculite. Transplanting was performed 35 days after sowing.

Black polyethylene pots $(8 \mathrm{~L})$ were filled with the commercial substrate Top Garden Floreira and maintained in a greenhouse, at spacing of $1 \mathrm{~m}$ between rows and $0.45 \mathrm{~m}$ between pots, with vertical training of the plants.

Irrigation was performed through a drip system, applying the required water demand, which was estimated using tensiometers installed in each treatment. The water retention curve of the commercial substrate was previously determined in 8 -L pots as a function of the tension measured through the tensiometers.

The salts sodium chloride and calcium chloride at the proportion of 2:1 were used in order to artificially salinize the irrigation water and, with the aid of a conductivity meter, the different levels of electrical conductivity for the irrigation water were determined $\left(0.3 ; 1.0 ; 2.0 ; 3.0\right.$ and $\left.4.0 \mathrm{dS} \mathrm{m}^{-1}\right)$.

The fertilizers recommended for the fertigation of the crop were added to the waters, following the recommendations for the crop development stages described by Campagnol (2009), obtaining the treatments composed of five solutions (saline waters + fertilizer) with the respective levels of electrical

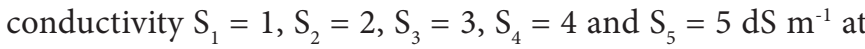
$25{ }^{\circ} \mathrm{C} \pm 0.2 \mathrm{dS} \mathrm{m}^{-1}$.

For each treatment, there was a tank with capacity for $500 \mathrm{~L}$ and a motor pump associated with the system of filters. Irrigation was performed through $1 / 2$-inch polyethylene tubes and drippers installed in the micro-tubes.

The treatments were arranged in randomized blocks, with four replicates (each replicate consisted of three pots, with one plant per pot).

Above each experimental block, a wire was supported by concrete posts at a height of $2.2 \mathrm{~m}$, from which a plastic narrow ribbon hung down to each pot. As the plant grew, the main stem was twisted around the plastic narrow ribbon. Plants were vertically trained until they reached height of $2.2 \mathrm{~m}$ and only then the apical meristem of the main stem was removed.

From the substrate of the pot until the height of 0.4 to $0.5 \mathrm{~m}$, all leaves and secondary branches of the plants were removed in order to discard old leaves and improve air circulation. In each secondary branch, the first four leaves were left and the rest of the branch was removed.

Since the beginning of flowering, all female flowers on the main stem until the height of $1.5 \mathrm{~m}$ from the base of the plant were daily and manually pollinated. When the fruits had diameter of approximately $0.10 \mathrm{~m}$, they were packed in nylon nets and suspended, thus preventing the fruit to fall off the plant due to its weight, leaving only one fruit per plant and removing the others.

At the end of the experiment, the main stem of mini watermelon plants was used to obtain the length of the main stem (SL), stem diameter (SD), number of leaves (NL) and number of secondary branches (NB).

Leaf area (LA) was obtained using an electronic meter (CI-203CA - CID Bio-Science), measuring the leaves of the main stem, which were also used for the determination of leaf fresh matter (LFM). After dried in a forced-air oven at 60 ${ }^{\circ} \mathrm{C}$, leaf dry matter (LDM) was determined and, based on the difference between LDM and LFM, leaf water content (LWC) was estimated.

For physico-chemical evaluations of fruits, eight fruits were harvested in each treatment, in a total of 40 . The fruits were collected and taken to the Laboratory of Fruits and Vegetables of the Department of Agri-food Industry, Food and Nutrition of the ESALQ/USP, for the analysis of fruit mass (FM), fruit diameter (FD), fruit pulp diameter (PD), rind thickness (RT) and pulp firmness (PF), as physical variables, and $\mathrm{pH}$, ascorbic acid (VC), soluble solids (SS), titratable acidity (TA) and the ratio of soluble solids/titratable acidity (SS/TA) of the pulp, as chemical variables.

The obtained results were subjected to analysis of variance; when significant, regression analysis was used to obtain the best-fit model to the data.

\section{Results AND Discussion}

There was significant effect of salinity on the variables: length of the main stem (SL), stem diameter (SD), number of 
leaves (NL) and number of secondary branches (NB) on the main stem. For the factor block, the effect was significant only for the variables SL and SD (Table 1).

The variables SL and NB showed reductions of 4.5 and $12.4 \%$, respectively, for each unit increase in the electrical conductivity of the irrigation water (Figure 1A, 1B). Leaf fresh matter (LFM), leaf dry matter (LDM) and leaf water content (LWC) and leaf area (LA) were significantly affected by salinity

Table 1. Summary of the analysis of variance for the variables length of the main stem (SL), stem diameter (SD), number of leaves $(\mathrm{NL})$ and number of secondary branches on the main stem (NB) in plants of mini watermelon, cV. Smile, irrigated with water of different saline concentrations $\left(1,2,3,4\right.$ and $\left.5 \mathrm{dS} \mathrm{m}^{-1}\right)$

\begin{tabular}{lccccc}
\hline \multirow{2}{*}{ SV } & \multirow{2}{*}{ DF } & \multicolumn{4}{c}{ Mean square } \\
\cline { 3 - 6 } & & SL & SD & NL & NB \\
Salinity (S) & 4 & $0.311^{\star *}$ & $1.121^{*}$ & $222.77^{\star}$ & $15.25^{\star *}$ \\
Block (C) & 3 & $0.204^{\star *}$ & $1.380^{\star}$ & $181.42^{\text {ns }}$ & $1.09^{\text {ns }}$ \\
Residual & 43 & 0.041 & 0.371 & 69.10 & 2.83 \\
CV (\%) & & 10.2 & 12.5 & 22.6 & 39.3 \\
\hline
\end{tabular}

* and ${ }^{* *}$ Significant at 0.05 and 0.01 probability levels by $F$ test, respectively; ${ }^{\text {ns Not significant; }}$ SV - Source of variation; DF - Degrees of freedom

A.
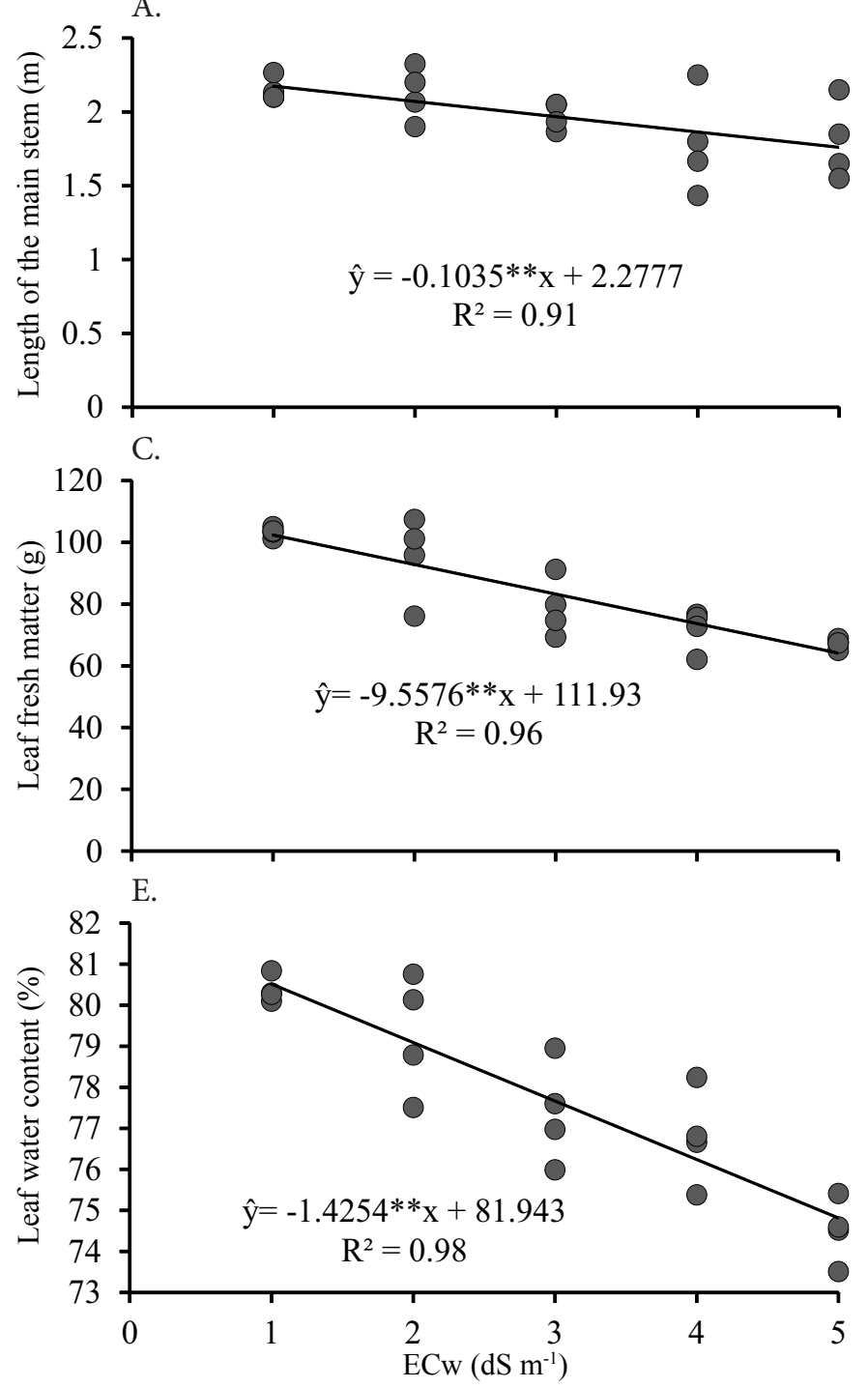

**Significant at 0.01 probability level by $\mathrm{F}$ test

Figure 1. Length of the main stem (A), number of secondary branches (B), leaf fresh matter (C), leaf dry matter (D), leaf water content $(\mathrm{E})$ and leaf area $(\mathrm{F})$ of plants of mini watermelon, cv. Smile, as a function of the saline concentrations (ECw)
(Table 2). The variable leaf water content (LWC) showed the lowest percent reduction $(1.7 \%)$ for each unit increase in the electrical conductivity of the irrigation water (Figure 1E); the other variables, LFM, LDM and LA showed reductions of 8.5, 4.3 and $13.4 \%$, respectively, when irrigation water salinity increased by $1 \mathrm{dS} \mathrm{m}^{-1}$ (Figure 1C, 1D, 1F).

Salinity negatively affected the variable number of leaves (NL), expressed by the equation $\hat{y}=-2.0583 \mathrm{X}+42.6$, showing significance at 0.05 probability level by $F$ test with $R^{2}$ of 0.51 .

Table 2. Summary of the analysis of variance for the variables leaf fresh matter (LFM), leaf dry matter (LDM), leaf water content (LWC) and leaf area (LA) in plants of mini watermelon, cv. Smile, irrigated with water of different saline concentrations $\left(1,2,3,4\right.$ and $\left.5 \mathrm{dS} \mathrm{m}^{-1}\right)$

\begin{tabular}{lccccc}
\hline \multirow{2}{*}{ SV } & \multirow{2}{*}{ DF } & \multicolumn{4}{c}{ Mean square } \\
\cline { 3 - 6 } & & LFM & LDM & LWC & LA \\
Salinity (S) & 4 & $952.83^{* *}$ & $9.8984^{*}$ & $20.836^{* *}$ & $4188411^{*}$ \\
Block (C) & 3 & $61.452^{\text {ns }}$ & $1.6704^{\text {ns }}$ & $0.3806^{\text {ns }}$ & $2402360^{\text {ns }}$ \\
Residual & 12 & 64.7265 & 3.2357 & 1.3340 & 873247 \\
CV (\%) & & 9.6 & 9.8 & 1.4 & 37.28 \\
\hline
\end{tabular}

* and ${ }^{* *}$ Significant at 0.05 and 0.01 probability levels by $F$ test, respectively; ${ }^{\text {ns } N o t ~ s i g n i f i c a n t ; ~}$ SV - Source of variation; DF - Degrees of freedom
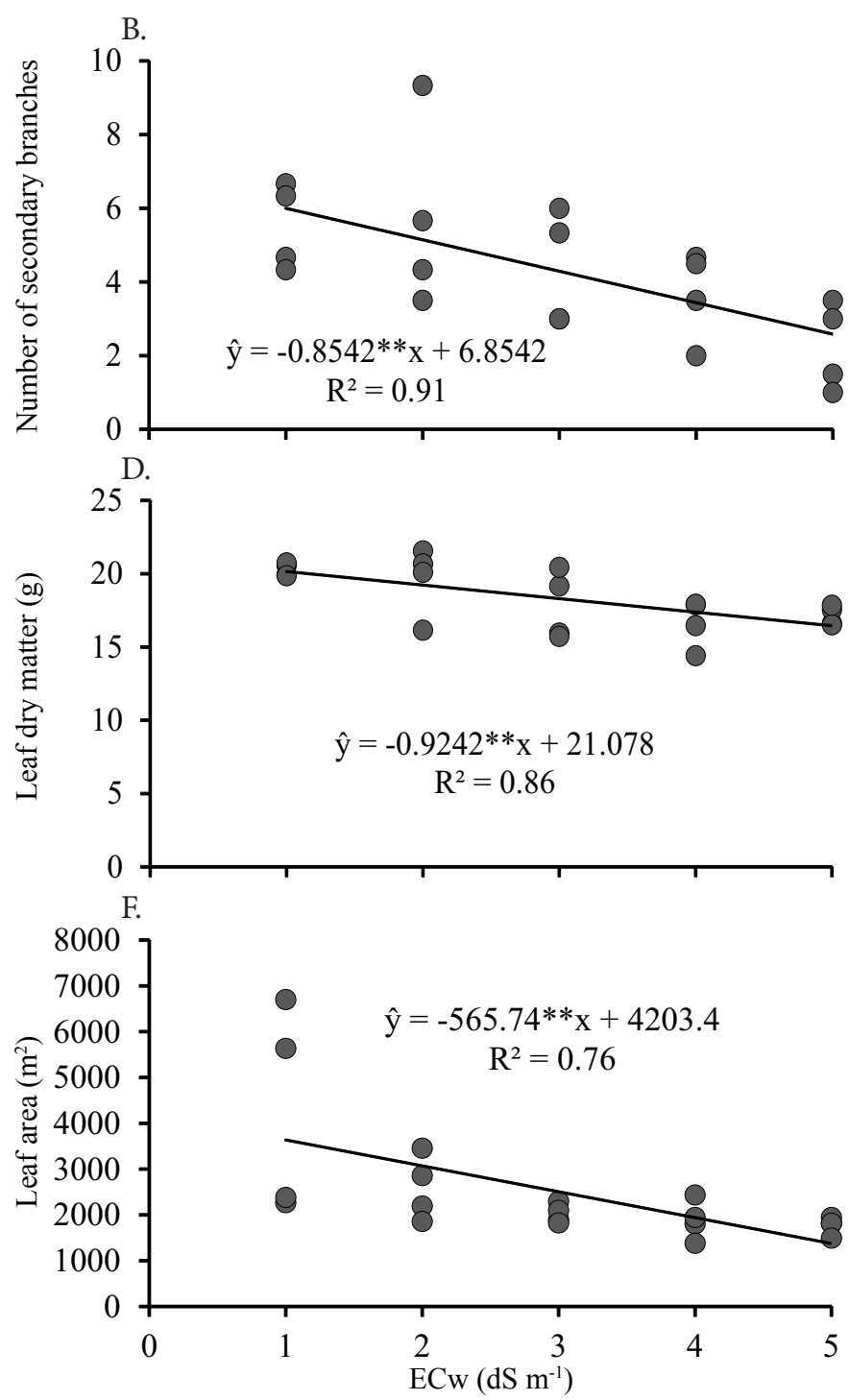
Some studies confirmed the negative effect of salinity on leaf dry matter and leaf area in watermelon (Martins et al., 2013); dry matter, plant height and number of leaves, in maize (Akbari et al., 2015); plant height, stem diameter, number of leaves, leaf area and leaf dry matter, in eggplant (Lima et al., 2015) and water content, shoot fresh matter and shoot dry matter, in basil (Bione et al., 2014).

According to Munns \& Tester (2008), the decrease in leaf area due to the stress caused by salinity is related to the difficulty of the plant to absorb water from the soil. Consequently, the decrease in leaf area will cause reduction of the area for transpiration in the plant, decreasing the release of water by the leaves and maintaining the soil wet.

The physical characteristics of the fruits, fruit mass (FM), fruit diameter (FD) and pulp diameter (PD), were affected by salinity (Table 3). For the variables rind thickness (RT) and pulp firmness (PF), there was no significant effect of salinity. There were reductions of 8.3 and 3.7, respectively, for the variables FM and FD for each unit increase in the electrical conductivity of the irrigation water (Figure 2A, 2B).

Medeiros et al. (2008), working with two melon hybrids, also observed that the increase in irrigation water salinity resulted in decrease in fruit mass, with reduction of $13.1 \%$ in the treatment of highest saline level $\left(4.5 \mathrm{dS} \mathrm{m}^{-1}\right)$ in comparison to the treatment of lowest saline level $\left(1.1 \mathrm{dS} \mathrm{m}^{-1}\right)$. Teodoro et al. (2004) worked with irrigation depths in the watermelon crop (Citrullus lanatus) and reported that watermelon yield was influenced by the shortage of water in the soil, with positive linear response from the lowest irrigation depth $(118.6 \mathrm{~mm})$ until the highest irrigation depth $(442.0 \mathrm{~mm})$. Munns \& Tester (2008) reported that the ions surrounding the roots tend to cause osmotic stress, compromising water absorption by plant roots. Thus, it can be assumed that the same behavior was observed in the present study, affecting the variables related to the mini watermelon yield (FM and FD).

The mean results for fruit diameter, pulp diameter and rind thickness of treatment $\mathrm{S} 1$ were similar to those obtained by Aumonde et al. (2011), who characterized fruits of mini watermelon, cv. Smile, grafted and ungrafted, produced without salt stress. Thus, it can be observed that the conditions and conduction of the present experiment were adequate for obtaining the variables FD, PD and RT compared with experimental conditions without saline stress.

The data of pulp firmness (PF) of mini watermelon corroborate with those of the study of Gurgel et al. (2010). Despite working with two melon varieties, these authors did
A.

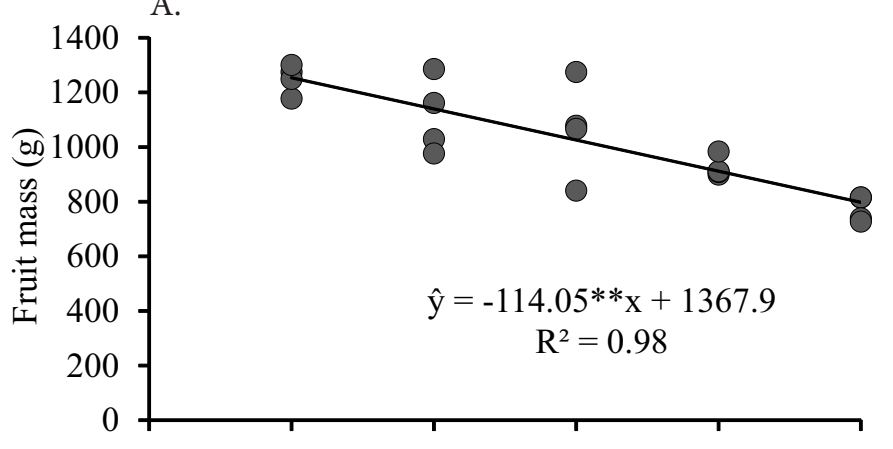

B.

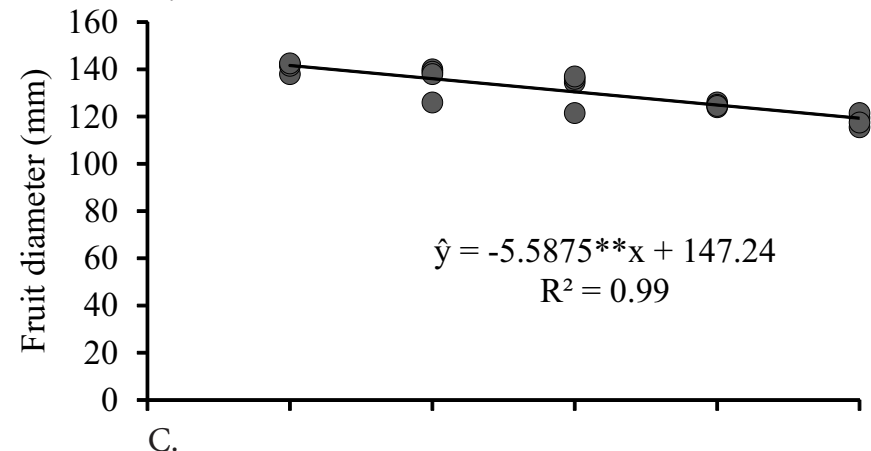

C.

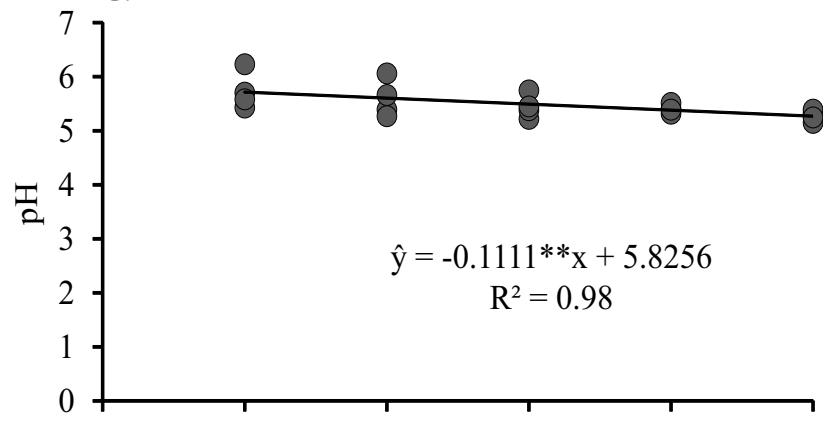

D.

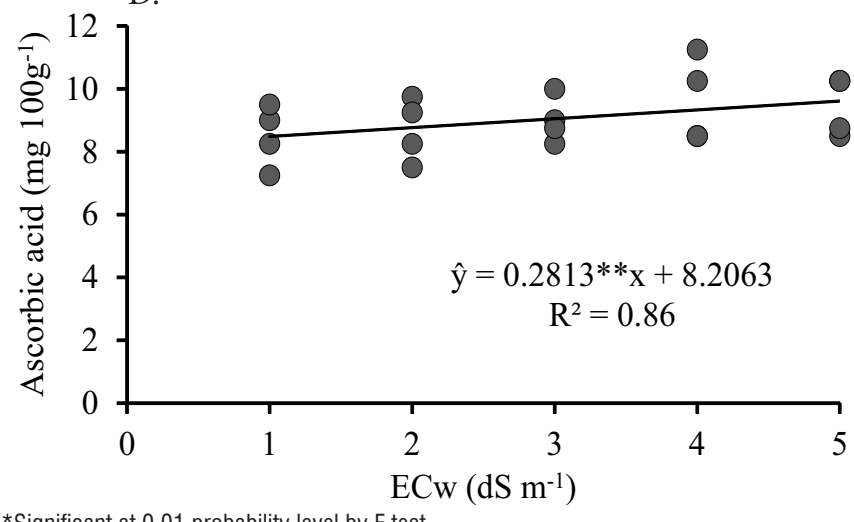

** Significant at 0.01 probability level by $\mathrm{F}$ test

Figure 2. Fruit mass (A), fruit diameter (B), $\mathrm{pH}(\mathrm{C})$ and ascorbic acid (D) of the pulp of fruits of mini watermelon, $\mathrm{cv}$. Smile, as a function of the saline concentrations (ECW)

Table 3. Summary of the analysis of variance for the variables: fruit mass (FM), fruit diameter (FD), pulp diameter (PD), rind thickness (RT), pulp firmness (PF), pH, ascorbic acid (VC), soluble solids (SS), titratable acidity (TA) and ratio of soluble solids/titratable acidity (SS/TA) of fruits of mini watermelon, cv. Smile, irrigated with water of different saline concentrations $\left(1,2,3,4\right.$ and $\left.5 \mathrm{dS} \mathrm{m}^{-1}\right)$

\begin{tabular}{|c|c|c|c|c|c|c|c|c|c|c|c|}
\hline \multirow{2}{*}{ SV } & \multirow{2}{*}{ DF } & \multicolumn{10}{|c|}{ Mean square } \\
\hline & & FM & FD & PD & RT & PF & $\mathrm{pH}$ & VC & SS & TA & SS/TA \\
\hline Salinity (S) & 4 & 266167 ** & $633.03^{* *}$ & $508.912^{\star \star}$ & $16.600^{\text {ns }}$ & $0.924^{\mathrm{ns}}$ & $0.253^{* *}$ & $1.834^{*}$ & $0.667^{\text {ns }}$ & $0.021^{\text {ns }}$ & $31.93^{\text {ns }}$ \\
\hline Block (C) & 3 & $19440^{\text {ns }}$ & $23.691^{\mathrm{ns}}$ & $32.733^{\text {ns }}$ & $22.158^{\text {ns }}$ & $0.791^{\mathrm{ns}}$ & $0.451 * \star$ & $6.516^{\star \star}$ & $14.87^{\star \star}$ & $0.652^{* *}$ & $597.15^{\star *}$ \\
\hline Residual & 32 & 12741 & 30.65 & 32.26 & 9.746 & 0.953 & 0.334 & 0.687 & 1.080 & 0.016 & 18.97 \\
\hline CV (\%) & & 11.0 & 4.2 & 4.7 & 29.2 & 38.2 & 3.3 & 9.1 & 9.0 & 18.0 & 23.3 \\
\hline
\end{tabular}

* and ${ }^{* \star}$ Significant at 0.05 and 0.01 probability level by F test, respectively; ${ }^{\text {ns }}$ - Not significant; SV - Source of variation; DF - Degrees of freedom 
not observe effect of irrigation water salinity on pulp firmness; on the other hand, Medeiros et al. (2011), working with yellow melon, Mandacaru hybrid, observed influence of irrigation water salinity on this variable.

Fruit mass was considered as the variable for measuring the relative yield of the mini watermelon. The relative value of $100 \%$ was attributed to the treatment of lowest salinity level $\left(S_{1}\right)$; hence, according to the regression line plotted on the graph proposed by Maas (1984), it is observed that the line of the relative yield of fruit mass classifies the mini watermelon, cv. Smile, as moderately sensitive to salinity (Figure 3).

For the variables referring to the chemical characteristics of mini watermelon fruits, $\mathrm{pH}$ and ascorbic acid (VC), there was significant effect of salinity (Table 3), with reduction of $1.9 \%$ for $\mathrm{pH}$ and increase of $3.4 \%$ in $\mathrm{VC}$, for each unit increase in the electrical conductivity of the irrigation water (Figure $2 \mathrm{C}, 2 \mathrm{D})$. For the other variables relative to the chemical characteristics of mini watermelon fruits, soluble solids (SS), titratable acidity (TA) and the ratio of soluble solids/titratable acidity (SS/TA), there was no significant effect of salinity.

The mean results for total soluble solids of the fruit pulp in the treatment $S_{1}$ were higher than those obtained by Aumonde et al. (2011), who also worked with mini watermelon, cv. Smile, grafted and ungrafted, but produced without saline stress. For the $\mathrm{pH}$ value, the mean results of the present study are similar to those obtained by Aumonde et al. (2011).

The negative response of $\mathrm{pH}$ as a function of irrigation water salinity was also observed by Dias et al. (2011), who worked with yellow passion fruit. These authors reported that the accumulation of salts in plant tissues from the irrigation water caused reduction in $\mathrm{pH}$, increasing the acidic character of the passion fruits.

The contents of vitamin $\mathrm{C}$ of the pulp of yellow passion fruits decreased with the increase in irrigation water salinity in the study of Dias et al. (2011), differing from the results of the present study. The authors also report that, in general, the content of vitamin $\mathrm{C}$ is related to sugars present in fruit juice, which was not observed in the present study.

For the variable soluble solids, Dias et al. (2011) reported negative effects in the pulp of yellow passion fruits as a function of irrigation water salinity, while Medeiros et al. (2010)

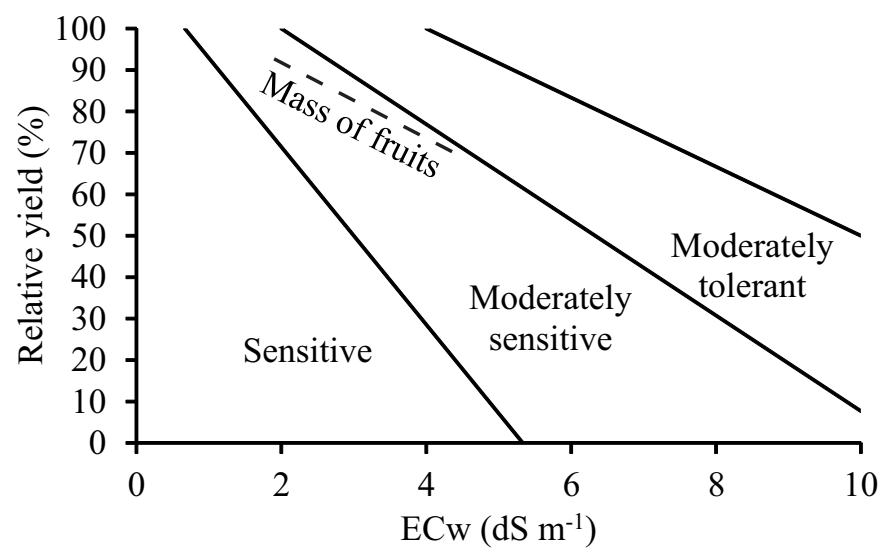

Figure 3. Relative yield (\%) of fruit mass of mini watermelon, cv. Smile, as a function of the saline concentrations (ECW) observed positive effect for the pulp of cucumber fruits as a function of soil salinity.

\section{Conclusions}

1. The mini watermelon, cv. Smile, has characteristics of crop moderately sensitive to irrigation water salinity.

2. Irrigation water salinity positively affected the variable ascorbic acid in the pulp of the fruits.

3. Irrigation water salinity negatively affected fruit mass, fruit diameter and pulp diameter, as well as $\mathrm{pH}$ of fruit pulp.

\section{ACKNOWLedgments}

To the Coordination for the Improvement of Higher Education Personnel (CAPES), for the scholarship, and the National Council for Scientific and Technological Development (CNPq), for funding the research.

\section{Literature Cited}

Akbari, M. M.; Mobasser, H. R.; Ganjali, H. R. Influence of salt stress and variety on some characteristics of corn. Biological Forum - An International Journal, v.7, p.441-445, 2015.

Aumonde, T. Z.; Lopes, N. F.; Peil, R. M. N.; Moraes, D. M.; Pedó, T.; Prestes, S. L. C.; Nora, L. Enxertia, produção e qualidade de frutos do híbrido de mini melancia Smile. Current Agricultural Science and Technology, v.17, p.1-5, 2011.

Bione, M. A. A.; Paz, V. P. da S.; Silva, F.; Ribas, R. F.; Soares, T. M. Crescimento e produção de manjericão em sistema hidropônico NFT sob salinidade. Revista Brasileira de Engenharia Agrícola e Ambiental, v.18, p.1228-1234, 2014. http://dx.doi. org/10.1590/1807-1929/agriambi.v18n12p1228-1234

Campagnol, R. Sistemas de condução de mini melancia cultivada em ambiente protegido. Piracicaba: ESAL/USP, 2009. 80p. Dissertação Mestrado. http://dx.doi.org/10.11606/d.11.2009.tde-10092009092331

Dias, T. J.; Cavalcante, L. F.; Freire, J. L. O.; Nascimento, J. A. M. do; Beckmann-Cavalcante, M. Z.; Santos, G. P. Qualidade química de frutos do maracujazeiro-amarelo em solo com biofertilizante irrigado com águas salinas. Revista Brasileira de Engenharia Agrícola e Ambiental, v.15, p.229-236, 2011. http://dx.doi. org/10.1590/S1415-43662011000300002

Gurgel, M. T.; Oliveira, F. H. T. de; Gheyi, H. R.; Fernandes, P. D.; Uyeda, C. A. Qualidade pós-colheita de variedades de melões produzidos sob estresse salino e doses de potássio. Revista Brasileira de Ciências Agrárias, v.5, p.398-405, 2010. http://dx.doi. org/10.5039/agraria.v5i3a507

John, L.; Marcondes, P. O valor da água: Primeiros resultados da cobrança nas Bacias PCJ. 1.ed. São Paulo: Camirim Editorial, 2010. 171p.

Lima, L. A.; Oliveira, F. A. de; Alves, R. C.; Linhares, P. S. F.; Medeiros, A. M. A. de; Bezerra, F. M. S. Tolerância da berinjela à salinidade da água de irrigação. Revista Agro@mbiente On-line, v.9, p.2734, 2015.

Maas, E. V. Salt tolerance of plants. In: Christie, B. R. (ed.) The handbook of plant science in agriculture. Boca Raton: CRC Press, 1984. Cap.2, p.57-75. 
Martins, D. C.; Ribeiro, M. S. S.; Souza Neta, M. L.; Silva, R. T.; Gomes, L. P.; Guedes, R. A. A.; Oliveira, F. A. Desenvolvimento inicial de cultivares de melancia sob estresse salino. Revista Agropecuária Científica no Semiárido, v.9, p.62-68, 2013.

Medeiros, D. C. de; Medeiros, J. F. de; Pereira, F. A. L.; Silva, S. C. M.; Amâncio, M. G. Production and quality of melon hybrid Mandacaru irrigated with different levels of salinity. Horticultura Brasileira, v.29, p.600-604, 2011. http://dx.doi.org/10.1590/S010205362011000400026

Medeiros, J. F. de; Duarte, S. R.; Fernandes, P. D.; Dias, N. da S.; Gheyi, H. R. Crescimento e acúmulo de N, P e K pelo meloeiro irrigado com água salina. Horticultura Brasileira, v.26, p.452-457, 2008. http://dx.doi.org/10.1590/S0102-05362008000400006
Medeiros, P. R. F.; Duarte, S. N.; Dias, C. T. S.; Silva, M. F. D. Tolerância do pepino à salinidade em ambiente protegido: Efeitos sobre propriedades físico-químicas dos frutos. Irriga, v.15, p.301-311, 2010. http://dx.doi.org/10.15809/irriga.2010v15n3p301

Munns, R.; Tester, M. Mechanisms of salinity tolerance. Annual Review of Plant Biology, v.59, p.651-681, 2008. http://dx.doi. org/10.1146/annurev.arplant.59.032607.092911

Sentelhas, P. C. Estimativa diária da evapotranspiração de referência com dados de estação meteorológica convencional e automática. Piracicaba: ESAL/USP, 1998. 97p. Tese Doutorado

Teodoro, R. E. F.; Almeida, F. P.; Luz, J. M. Q.; Melo, B. de. Diferentes lâminas de irrigação por gotejamento na cultura de melancia (Citrullus lanatus). Bioscience Journal, v.20, p.29-32, 2004. 